\title{
Senyawa Daun Rasamala (Altingia excelsa Nornha) sebagai Penghambat Proliferasi Sel Kanker Lidah Manusia In Vitro
}

Rasamala Leaves Compound (Altingia excelsa Nornha) as an Inhibitor of Human Tongue Cancer Cell Proliferation in Vitro

Risyandi Anwar, ${ }^{*}$ Arlette Setiawan, ${ }^{2}$ Supriatno ${ }^{3}$, Unang Supratman ${ }^{4}$

1 Bagian Ilmu Kedokteran Gigi Anak, Fakultas Kedokteran Gigi Universitas Muhammadiyah Semarang

2 Bagian Ilmu Kedokteran Gigi Anak, Fakultas Kedokteran Gigi, Universitas Padjadjaran

3 Bagian Penyakit Mulut, Fakultas Kedokteran Gigi, Universitas Gajah Mada

4 Jurusan Kimia, Fakultas matematika dan Ilmu Pengetahuan Alam, Universitas Padjadjaran

\section{Abstrak}

Kanker lidah merupakan penyakit ganas yang umum terjadi di rongga mulut dan hingga saat ini secara medis berhasil menyembuhkan sehingga sering dirawat kehidupan. Tujuan penelitian adalah untuk mengidentifikasi matabolitas sekunder daun Rasamala, menguji senyawa daun Rasamala terhadap penghambatan pertumbuhan sel SP-Cl. Desain laboratorium eksperimental yang benar menggunakan garis sel kanker lidah mulut SP-Cl digunakan. Ekstrak etil asetat dipisahkan metabolit sekundernya dengan berbagai teknik kromatografi berpedoman pada aktivitas antiproliferasi untuk menghasilkan lima senyawa, yaitu asam 3,4-dihidroksi benzoat (1), asam galat (2), dan apigenin (3). Senyawa 1-3 diuji aktivitas antiproliferatifnya terhadap sel kanker lidah SP-C1 dan menunjukkan nilai IC50 masing-masing 100, Â100, dan Â $100 \mu \mathrm{g} / \mathrm{mL}$. Analisis data menggunakan uji ANACOVA, Tukey HSD dengan taraf signifikansi $a=0,05$. Kesimpulannya, senyawa dari daun rasamala memiliki aktivitas antikanker yang kuat pada kanker mulut mulut manusia SP-C1 melalui penghambatan prolierasi sel.

Kata kunci : Altingia excelsa, anti proliferatif, apigenin. asam benzoat 3,4-dihidroksi, asam galat, kanker mulut manusia SP-C1,

\begin{abstract}
Tongue cancer is a common malignant in the oral cavity and to now medically succes its no good so often treated of life. The aims of study were to identify the secondary matabolities of Rasamala leaves, to examine the compound of Rasamala leaves toward SP-Cl cell growth inhibition. True experimental laboratories design using SP$\mathrm{Cl}$ oral tongue cancer cell line was used. The ethyl acetate extract was separated their secondary metabolites by various chromatographic techniques guided by antiproliferasi activity to yield five compounds, as 3,4-dihydroxy benzoic acid (1), gallic acid (2), and apigenin (3). Compounds 1-3 were tested on their antiproliferative activity against cancer cells tongue SP-Cl and showed $I C_{50}$ values of $\hat{A} 100, \hat{A} 100$, and $\hat{A} 100 \mu g / m L$, respectively. Data analysis using ANACOVA assay, Tukey HSD with the level of significance $a=0.05$. In conclusion, compound from Rasamala leaves have a strong anticancer activity in human oral tongue cancer SP-Cl through inhibit cell prolieration.
\end{abstract}

Keywords : 3,4-dihydroxy benzoic acid, apigenin, gallic acid, human oral tongue cancer SP-Cl, Altingia excelsa, anti-proliferative

Korespondensi (Correspondence) : Risyandi Anwar. Bagian Ilmu Kedokteran Gigi Anak, Fakultas Kedokteran Gigi Universitas Muhammadiyah Semarang, Jalan Kedungmundu Raya no.22 Semarang Email:

Kanker merupakan penyebab kematian nomor dua dunia setelah penyakit kardiovaskular, dengan persentase $12 \% .1$ Angka kejadian kanker pada rongga mulut di dunia berkisar antara 3-5\%, dan lebih dari $90 \%$ kanker rongga mulut merupakan karsinoma sel skuamosa (Oral Squamous Cell Carcinoma/OSCC) dan merupakan keganasan yang paling banyak terjadi di rongga mulut.2,3 Beberapa lokasi yang dapat terkena kanker pada rongga mulut antara lain bibir, mukosa bukal, daerah alveolar atas dan bawah, trigonum retromolar, palatum keras, dasar mulut dan dua pertiga anterior lidah. ${ }^{4}$ Perawatan karsinoma sel skuamosa rongga mulut saat ini terutama dilakukan dengan pembedahan, radioterapi, kemoterapi dan kombinasi.5,6 Kegagalan yang sering terjadi dalam usaha pengobatan kanker, utamanya melalui kemoterapi, lebih disebabkan rendahnya selektivitas obat-obat anti kanker dan sensitivitas sel kanker itu sendiri terhadap agen kemoterapi. ${ }^{5}$ Pendekatan terapi kanker dapat dilakukan dengan menghambat perkembangan sel kanker tersebut salah satunya dengan cara penghambatan proliferasi yang dapat teramati secara in vitro. ${ }^{7}$ Usaha penemuan obat baru yang aman dan selektif terhadap pengobatan dan pencegahan kanker dengan mengetahui pengaruh molekuler terhadap sel kanker perlu dilakukan, salah satunya dengan cara pencarian senyawa kimia dari alami dengan memanfaatkan kekayaan alam. ${ }^{8}$

Sejak zaman prasejarah manusia telah memanfaatkan ekstrak tanaman untuk pengobatan berbagai penyakit. Sebanyak $60 \%$ populasi penduduk dunia bergantung pada pengobatan tradisional dan $80 \%$ nya berada di negara berkembang. ${ }^{9}$ Obat herbal sangat berperan secara signifikan terhadap 
pengembangan obat sintesis, sebanyak $60 \%$ obat antikanker dan $75 \%$ obat penyakit infeksi yang dikeluarkan tahun 1981-2002 dapat dirunut ke bahan alam. ${ }^{\text {National }}$ cancer institute ( $\mathrm{NCl}$ Amerika Serikat juga mengembangkan penelitian tentang penggunaan bahan alam untuk terapi kanker karena banyak ditemukan obat antikanker yang berasal dari berbagai tanaman. ${ }^{10}$ Salah satu famili dalam tumbuhan yang banyak diteliti untuk pengobatan antikanker adalah Hamamelidaceae. Beberapa tumbuhan dari famili Hamamelidaceae yang pernah diteliti sebagai antikanker di antaranya adalah Liquidambar styraciflua. ${ }^{11-13 T u m b u h a n ~ l a i n ~ d a r i ~}$ famili hammamelidaceae yang pernah diteliti untuk antikanker adalah L. Formosana dan corylopsis coreana Uyeki. ${ }^{14-17}$

Salah satu tumbuhan yang termasuk famili Hamamelidaceae dan genus Altingia dan hanya tumbuh di daratan Asia serta banyak tersebar di Jawa Barat adalah Rasamala (Altingia excelsa Nornha) yang hidup di daerah tropis dan dataran tinggi, terutama di daerah pegunungan Jawa Barat. 18 Penelitian terhadap daun Rasamala yang berasal dari daerah Arunachal Prades India, dan mendapatkan minyak atsiri yaitu monoterpen sebagai komponen utama dan seskuiterpen sebagai komponen minor pernah dilakukan. ${ }^{19}$ Tumbuhan yang memiliki hubungan taksonomi yang dekat, seperti satu famili atau satu genus akan memiliki aktivitas yang hampir sama. 20 Rasamala (Altingia excelsa Nornha) diharapkan memiliki kandungan senyawa kimia yang mempunyai aktivitas sebagai antikanker.

\section{METODE PENELITIAN}

Spektra Ultra-violet diukur dalam methanol pada spektrofotometer jasco UV1575. Spektra IR diukur pada Perkin Elmer spectrum-100 dalam KBr. Spektra NMR diukur dalam JEOL JNM A-500 spectrometer menggunakan tetra methyl silane (TMS) sebagai standar. Pemisahan dilakukan dengan berbagai teknik kromatografi dengan silica gel 60 (Merck). Plat TLC silica gel GF254 (Merck, $0.25 \mathrm{~mm}$ ) dan dideteksi dengan $10 \%$ $\mathrm{H} 2 \mathrm{SO} 4$ dalam etanol, dilanjutkan dengan pemanasan. Sedangkan untuk uji proliferasi sel kanker SP-Cl alat dan bahan yang digunakan adalah DMEM, DMSO, trypsinEDTA, ELISA microplate reader (BioRedJepang), plate 96 sumuran (Iwaki-Jepang), labu takar $15 \mathrm{~mL}$ dan $50 \mathrm{~mL}$ (EppendoffJerman), waterbath (Eyele-Jepang), multichannel micropippet (Effendorf-Jerman), inkubator $37^{\circ} \mathrm{C}-\mathrm{CO}_{2} \quad 5 \%$ (Sanyo-Jepang), neraca digital elektronik (Metler -Swiss), Laminar Flow (Sanyo-Jepang), lampu spirtus, mikroskop (Nikon Eclipse-Jepang), Kamera (Sony-Jepang).

Sampel yang digunakan adalah daun rasamala yang diperoleh dari pegunungan Wayang Windu, Pangalengan, Bandung dan dideterminasi di Laboratorium Taksonomi
Tumbuhan, Departemen Biologi, Fakultas Matematika dan IImu Pengetahuan Alam, Universitas Padjadjaran. Subjek penelitian ini adalah sel kanker lidah manusia Supri's Clone 1 (SP-C1). SP-Cl merupakan sel kanker lidah yang diisolasi dari limfonadi penderita kanker lidah, berasal dari karsinoma sel skuamosa sedang dan belum mengalami invasi ke jaringan otot. ${ }^{21}$

\section{Ekstraksi daun Rasamala}

Daun kering Rasamala (2,5 kg) dimaserasi dengan metanol pada suhu kamar selama 24 jam dan dilakukan penampungan maserat sebanyak tiga kali. Maserat yang diperoleh kemudian dipekatkan dengan rotary evaporator sampai diperoleh maserat pekat metanol. Maserat pekat metanol dilarutkan dalam air, kemudian dipartisi dengan $n$-heksana dan dihasilkan ekstrak $n$ heksan dan air. Ekstrak n-heksan dipisahkan dan dipekatkan dengan rotary evaporator, dihasilkan ekstrak pekat $n$-heksan. Lapisan air yang diperoleh kemudian dipartisi dengan etil asetat dihasilkan ekstrak etil asetat dan air. Ekstrak etil asetat dipisahkan dan dipekatkan dengan rotary evaporator, dihasilkan ekstrak pekat etil asetat (120 g). Masing-masing ekstrak dilakukan uji antiproliferasi terhadap sel kanker lidah SP-Cluntuk diketahui ekstrak mana yang paling aktif sebagai antikanker yang diselanjutnya ekstrak tersebut akan di isolasi.

\section{Isolasi ekstrak Etil Asetat sebagai ekstrak teraktif}

Ekstrak etil asetat (120 g) dipisahkan dengan kromatografi cair vakum (KCV) pada fasa diam silika gel $\mathrm{G}_{60}$ dengan fasa gerak nheksana-etil asetat -metanol dengan gradien $10 \%(\mathrm{v} / \mathrm{v})$, setelah digabungkan berdasarkan analisis kromatografi lapis tipis (KLT) diperoleh lima fraksi utama (A-E), dan kemudian dilakukan uji aktivitas antiproliferasi ke lima fraksi tersebut. Berdasarkan nilai IC50 berbagai fraksi hasil uji antiproliferasi tersebut, yang mempunyai potensi sebagai antiproliferasi adalah Fraksi C. Fraksi C (26 g) dipisahkan lebih lanjut dengan kromatografi cair vakum (KCV) pada fasa diam silika gel $G_{60}$ dengan fasa gerak $n$-heksan-etil asetatmetanol dengan gradien $10 \%(\mathrm{v} / \mathrm{v})$, setelah digabungkan berdasarkan analisis kromatografi lapis tipis (KLT) diperoleh lima fraksi $\left(\mathrm{C}_{1}-\mathrm{C}_{5}\right)$, dan kemudian dilakukan uji aktivitas antiproliferasi ke lima fraksi tersebut. Berdasarkan nilai $I C_{50}$ hasil uji antiproliferasi di atas, menunjukkan bahwa Fraksi $\mathrm{C}_{3}$ dan $\mathrm{C}_{5}$ memberikan aktivitas potensi sebagai antikanker. Fraksi $C_{3}(6 \mathrm{~g})$ dipisahkan lebih lanjut dengan kromatografi kolom (KK) pada fasa diam silika gel (70-230 mesh) dengan fasa gerak $n$-heksan:etil asetat bergradien $10 \%(\mathrm{v} / \mathrm{v})$ sehingga diperoleh empat fraksi utama $\left(\mathrm{C}_{31}-\mathrm{C}_{34}\right)$ setelah digabungkan berdasarkan analisis KLT, dan dilakukan uji aktivitas antiproliferasi keempat fraksi tersebut. Berdasarkan nilai IC $C_{50}$ uji antiproliferasi, terlihat 
bahwa fraksi $C_{32}$ mempunyai potensi sebagai antiproliferasi. Fraksi $C_{32}(2 \mathrm{~g})$ dipisahkan lebih lanjut dengan kromatografi kolom (KK) pada fasa diam silika gel (70-230 mesh) dengan fasa gerak $n$-heksan:aseton sehingga diperoleh empat fraksi $C_{321}-C_{324}$. Fraksi $C_{321}$ dihasilkan padatan amorf dan direkristalisasi lebih lanjut dengan campuran nheksan:metanol (4:1), diperoleh senyawa 1 berbentuk kristal putih (7 mg).

Fraksi C5 (6 g) dipisahkan lebih lanjut dengan kromatografi kolom (KK) pada fasa diam silika gel (70-230 mesh) dengan fasa gerak $n$-heksan-etil asetat bergradien $5 \%$ sehingga diperoleh lima fraksi utama $\mathrm{C}_{51}-\mathrm{C}_{55}$. Pada $\mathrm{C}_{51}$ dihasilkan padatan amorf dan direkristalisasi lebih lanjut dengan campuran n-heksan:metanol (4:1), diperoleh senyawa 2 berbentuk kristal putih (8 $\mathrm{mg}$ ), dan kemudian dilakukan uji aktivitas antiproliferasi ke tiga fraksi yang tersisa yaitu $\mathrm{C}_{52}, \mathrm{C}_{53}$ dan $\mathrm{C}_{54}$ Berdasarkan persentase kematian sel dan nilai $I_{50}$ uji antiproliferasi tersebut diatas, fraksi $\mathrm{C}_{53}$ mempunyai potensi sebagai antiproliferasi. Fraksi $\mathrm{C}_{53}$ dipisahkan lebih lanjut dengan kromatografi kolom (KK) pada fasa diam silika gel (70-230 mesh) dengan fasa gerak nheksana:aseton (7:3) dihasilkan padatan amorf dan direkristalisasi lebih lanjut dengan campuran $n$-heksan:metanol (4:1), diperoleh senyawa 3 berbentuk kristal putih ( $13 \mathrm{mg}$ ).

\section{Penentuan struktur senyawa 1-3}

Senyawa hasil isolasi ditetapkan sifat fisiknya meliputi warna dan titik lelehnya. Struktur kimia senyawa ditentukan berdasarkan data-data spektroskopi meliputi Ultra-Violet (UV), inframerah (IR), resonansi magnetik inti proton ('H-NMR), karbon (13CNMR), Distontiorless Enhancement by Polarization Transfer (DEPT), dan massa, serta perbandingan dengan data spektra yang diperoleh dari literatur. ${ }^{22}$

\section{Biakan Sel Kanker Lidah SP-C1}

Jaringan sel kanker lidah SP-Cl dimasukkan ke dalam Flash (Falcon, USA) berisi DMEM yang ditambah Fetal Bovine Serum 10 \% (FBS, morregate, BioTech, Australia), Fungizone liquid $5 \mathrm{ml}$ (Gibco, USA). Sel kanker diinkubasi dengan kelembaban udara $95 \%$ dan $\mathrm{CO}_{2} 5 \%$ pada suhu $37^{\circ} \mathrm{C}$. Dibiakan dalam flash dan diinkubasi pada suhu $370^{\circ} \mathrm{C}$ selama 24 jam. Setiap 4-5 hari medium DMEM harus diganti dengan medium yang baru, sampai jumlah sel kanker dapat dipanen. Setelah jumlah sel telah memenuhi flash (dapat dilihat di bawah microskop), medium diaspirasi, kemudian dicuci dengan PBS steril $5 \mathrm{ml}$ selama 1 menit, kemudian diaspirasi lagi. Dimasukkan larutan trypsinEDTA $0,25 \% \quad l \quad \mathrm{ml}$ pada masing-masing petridish, kemudian diinkubasi pada suhu $37^{\circ} \mathrm{C}$ selama 5 menit. Sel diberi RPMI untuk menghentikan EDTA. Semua sel dipanen dan dimasukkan dalam conical tube $20 \mathrm{ml}$. Sel di ambil menggunakan pipet dan dimasukan ke dalam haemocytometer untuk menghitung banyaknya sel per plate

\section{Uji antiprolierasi sel MTT Assay}

Disiapkan 5 buah plate yang berisi 96 sumuran, untuk pengujian MTT Assay jam ke 24. Kemudian pada masing-masing plate masukkan sel kanker lidah SP-C 1 sebanyak $1 \mathrm{X}$ $10^{4} \mathrm{sel} /$ sumuran di tambahkan $100 \mu \mathrm{L}$ DMEM (Dulbelco's Modified Eagle Medium) sesuai dengan konsentrasi senyawa. Semua sel kemudian diinkubasikan pada suhu $37^{\circ} \mathrm{C}$ selama 24 jam. Setelah 24 jam setiap 96 well plate di tambahkan MTT sebanyak $15 \mu \mathrm{L}$ per sumuran. Medium diinkubasi pada suhu $37^{\circ} \mathrm{C}$ selama 4 jam. Larutan dibuang, kemudian

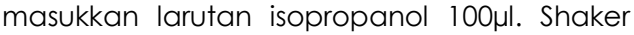
10-15 menit sampai homogen. Plate 96 sumuran diukur dengan Bio-Rad Microplate Reader dengan panjang gelombang $540 \mathrm{~nm}$.

\section{HASIL}

Hasil uji antiproliferasi ekstrak menunjukan ekstrak etil asetat merupakan ekstrak teraktif (Tabel 1), sehingga ekstrak etil asetat dilanjutkan untuk diisolasi. Hasil perbandingan senyawa 1 dan 2 menunjukkan bahwa kedua senyawa memiliki kesesuaian yang sangat tinggi, dengan demikian dapat disimpulkan bahwa senyawa 1 adalah asam 3,4-dihidroksi benzoat seperti yang ditunjukan pada gambar 1 dan tabel 2. Sedangkan, hasil perbandingan senyawa 3 menunjukkan bahwa kedua senyawa memiliki kesesuaian yang sangat tinggi (Tabel 4), sehingga senyawa 3 diidentifikasi sebagai apigenin (Gambar 3).

Tabel 1. Nilai $I C_{50}$ berbagai ekstrak daun Rasamala.

\begin{tabular}{lc}
\hline Ekstrak & $\mathrm{IC}_{50}(\boldsymbol{\mu g} / \mathbf{m L})$ \\
\hline Methanol & 75,41 \\
n-heksan & 44,85 \\
etil asetat & 12,85 \\
Air & 18,02 \\
\hline
\end{tabular}<smiles>O=C(O)c1ccc(O)c(O)c1</smiles>

Gambar 1. asam 3,4-dihidroksi benzoat 
Tabel 2. Perbandingan data NMR senyawa 1 dengan asam 3,4-dihidroksi benzoat (Gurial et al., 2013)

\begin{tabular}{|c|c|c|c|c|}
\hline \multirow[b]{2}{*}{ Posisi C } & \multicolumn{2}{|c|}{ Senyawa 1 (aseton- $d_{6}$ ) } & \multicolumn{2}{|c|}{ asam 3,4-dihidroksi benzoat (DMSO- $d_{6}$} \\
\hline & $\delta_{c}(\mathrm{ppm})$ & $\delta_{H}(\mathrm{ppm}), \mathbf{\Sigma} \mathbf{H}, \mathrm{mult}, \mathrm{J}(\mathrm{Hz})$ & $\delta_{c}(\mathrm{ppm})$ & $\delta_{H}(\mathrm{ppm}), \mathbf{\Sigma} \mathbf{H}, \mathrm{mult}, J(\mathrm{~Hz})$ \\
\hline 1 & 123,1 & - & 122,0 & - \\
\hline 2 & 117,5 & $7,46(2 \mathrm{H}, \mathrm{d}, 1,9 ; 8,4)$ & 116,9 & $7,31(2 \mathrm{H}, d, 2,1 ; 8,1)$ \\
\hline 3 & 145,6 & - & 145,2 & - \\
\hline 4 & 150,7 & - & 150,3 & - \\
\hline 5 & 115,7 & $6,88(1 \mathrm{H}, \mathrm{d}, 8,4)$ & 115,5 & $6,80(1 \mathrm{H}, \mathrm{d}, 8,1)$ \\
\hline 6 & 123,7 & $7,50(1 \mathrm{H}, d, 1,9)$ & 122,3 & $7,36(1 \mathrm{H}, \mathrm{d}, 2,1)$ \\
\hline $\mathrm{CO}_{2} \mathrm{H}$ & 167,6 & - & 167,7 & - \\
\hline
\end{tabular}

Tabel 3. Perbandingan data NMR senyawa 2 dengan asam galat (Gangadhar et al., 2011)

\begin{tabular}{|c|c|c|c|c|}
\hline \multirow[b]{2}{*}{ Posisi C } & \multicolumn{2}{|c|}{ Senyawa 2 (aseton-do) } & \multicolumn{2}{|c|}{ Asam galat $\left(\mathrm{CD}_{3} \mathrm{OD}\right)$} \\
\hline & $\delta_{c}(\mathrm{ppm})$ & $\delta_{H}(p p m), \Sigma \mathbf{H}$, mult, J (Hz) & $\delta_{c}(\mathrm{ppm})$ & 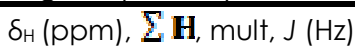 \\
\hline 1 & 122,2 & - & 120,6 & - \\
\hline 2 & 110,7 & $7,15(1 \mathrm{H}, \mathrm{s})$ & 108,9 & $7,07(1 \mathrm{H}, \mathrm{s})$ \\
\hline 3 & 145,9 & - & 144,9 & - \\
\hline 4 & 138,6 & - & 138,2 & - \\
\hline 5 & 145,9 & - & 144,9 & - \\
\hline 6 & 110,7 & $7,15(1 \mathrm{H}, \mathrm{s})$ & 108,9 & $7,07(1 \mathrm{H}, \mathrm{s})$ \\
\hline $\mathrm{CO}_{2} \mathrm{H}$ & 167,7 & - & 169,0 & - \\
\hline
\end{tabular}

Tabel 4. Perbandingan data spektroskopi NMR senyawa 3 dengan apigenin (Ogihara, 2011)

\begin{tabular}{|c|c|c|c|c|}
\hline \multirow[b]{2}{*}{ Posisi C } & \multicolumn{2}{|c|}{ Senyawa 3 (aseton- $d_{6}$ ) } & \multicolumn{2}{|l|}{ apigenin $\left(\mathrm{CD}_{3} \mathrm{OD}\right)$} \\
\hline & $\delta^{\mathrm{H}}(\mathrm{ppm}), \Sigma \mathbf{H}$, mult, $(\mathrm{J} \mathrm{Hz})$ & $\delta^{c}(\mathrm{ppm})$ & $\left.\delta^{\mathrm{H}}(\mathrm{ppm}), \boldsymbol{\Sigma} \mathbf{H}, \mathrm{mult}, \mathrm{J}=\mathrm{Hz}\right)$ & $\delta^{c}(\mathrm{ppm})$ \\
\hline 2 & - & 165,9 & 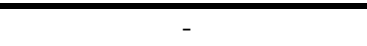 & 164,4 \\
\hline 3 & $6,51(1 \mathrm{H}, \mathrm{s})$ & 103,4 & $6,58(1 \mathrm{H}, \mathrm{s})$ & 104,2 \\
\hline 4 & - & 183,5 & - & 182,4 \\
\hline 5 & $6,34(1 \mathrm{H}, \mathrm{d}, 1,9)$ & 163,2 & $6,83(1 \mathrm{H}, d, 2,1)$ & 163,9 \\
\hline 6 & - & 101,5 & - & 100,8 \\
\hline 7 & $6,11(1 \mathrm{H}, d, 1,9)$ & 167,3 & $6,71(1 \mathrm{H}, \mathrm{d}, 2,1)$ & 165,2 \\
\hline 8 & - & 96,1 & - & 97,3 \\
\hline 9 & - & 159,8 & - & 160,7 \\
\hline 10 & - & 105,0 & - & 105,1 \\
\hline $1^{\prime}$ & - & 123,2 & - & 123,1 \\
\hline $2^{\prime}, 6^{\prime}$ & $7,83(2 \mathrm{H}, d, 9,1)$ & 129,4 & $7,83(1 \mathrm{H}, d, 8,8)$ & 129,3 \\
\hline $3^{\prime}, 5^{\prime}$ & $6,91(1 \mathrm{H}, \mathrm{d}, 9,1)$ & 117,3 & $6,92(1 \mathrm{H}, d, 8,8)$ & 117,6 \\
\hline $4^{\prime}$ & - & 163,1 & - & 162,6 \\
\hline
\end{tabular}<smiles>O=C(O)c1cc(O)c(O)c(O)c1</smiles>

Gambar 2. Struktur asam galat.<smiles>O=c1cc(-c2ccc(O)cc2)oc2cc(O)cc(O)c12</smiles>

Gambar 3. Struktur apigenin
Tabel 5. Nilai $\mathrm{IC}_{50}$ Senyawa 1-3 terhadap sel kanker lidah SP-Cl

\begin{tabular}{cc}
\hline Senyawa & $\mathbf{I C}_{50}(\boldsymbol{\mu g} / \mathbf{m L})$ \\
\hline $\mathbf{1}$ & 23,45 \\
$\mathbf{2}$ & 17,92 \\
$\mathbf{3}$ & 12,96
\end{tabular}

\section{PEMBAHASAN}

Dengan dipandu dengan uji antiproliferasi, terhadap ekstrak etil asetat dilakukan metode pemisahan dan pemurnian hingga diperoleh tiga senyawa.

\section{Senyawa 1}

Senyawa 1 diperoleh sebagai padatan putih, titik leleh $249-251{ }^{\circ} \mathrm{C}$, UV $(\mathrm{MeOH}) \lambda_{\text {maks }}$ $\mathrm{nm} 292(\log \varepsilon 2,4), 323(\log \varepsilon 2,7)$ dan $364(\log$ $\varepsilon$ 3,7); IR (KBr) Umaks $\mathrm{cm}^{-1}: 3420,1648,1437$, 1019; 'H-NMR (aseton-d $6,500 \mathrm{MHz}) \delta_{\mathrm{H}}$ (ppm) $7,46(1 \mathrm{H}, \mathrm{dd}, J=1,9 ; 8,4 \mathrm{~Hz}, \mathrm{H}-6), 6,88(1 \mathrm{H}, d, J=$ $8,4 \mathrm{~Hz}, \mathrm{H}-5), 7,55(1 \mathrm{H}, d, J=1,9 \mathrm{~Hz}, \mathrm{H}-2),{ }^{13} \mathrm{C}-\mathrm{NMR}$ (aseton-do, $125 \mathrm{MHz}$ ) $\delta c$ (ppm): 123,1 (C-1), 
117,5 (C-2), 145,6 (C-3), 150,7 (C-4), 115,7 (C5), dan $123,7(\mathrm{C}-6)$.

\section{Struktur kimia Senyawa 1}

Senyawa 1 diperoleh berupa padatan putih dengan titik leleh $249-251^{\circ} \mathrm{C}$. Spektrum UV senyawa 1 menunjukkan adanya tiga pita serapan pada $\lambda_{\text {maks }} 292,323$ dan $364 \mathrm{~nm}$. Spektrum IR (Gambar 4.5) menunjukkan adanya vibrasi pada $v_{\text {maks }} 3420 \mathrm{~cm}^{-1}$ dengan puncak yang lebar dan tajam yang diduga berasal dari gugus - $\mathrm{OH}$ yang membentuk ikatan hidrogen. Keberadaan gugus $-\mathrm{OH}$ ini diperkuat pula dengan munculnya regang $\mathrm{C}$ O pada $V_{\text {maks }} 1020 \mathrm{~cm}^{-1}$. Spektrum'H NMR senyawa 1, menunjukkan kehadiran tiga sinyal proton dengan sistem $A B X$ yang beresonansi pada $\delta_{\mathrm{H}} 7,50 \mathrm{ppm}(1 \mathrm{H}, d, J=1,9 \mathrm{~Hz}, \mathrm{H}-2), 7,46$ ppm $(1 \mathrm{H}$, dd, $J=1,9$ dan $8,4 \mathrm{~Hz}, \mathrm{H}-6)$ dan 6,88 ppm $(1 \mathrm{H}, d, J=8,4 \mathrm{~Hz}, \mathrm{H}-5)$. Multiplisitas dari sinyal tersebut merupakan ciri adanya sistem $A B X$ dari senyawa aromatik. Spektrum ${ }^{13} \mathrm{C}$ NMR menunjukkan adanya tujuh sinyal karbon yang terdiri atas satu karbon karbonil yang beresonansi pada $\delta \mathrm{c} 167,6 \mathrm{ppm}$ dan sinyal $\mathrm{CH}$ $\mathrm{sp}^{2}$ yang beresonansi pada $\delta c$ 150,7-115,7 ppm. Berdasarkan spektrum DEPT 135 diketahui bahwa terdapat tiga metin $\mathrm{sp}^{2}$ dan empat karbon kuarterner $s p^{2}$. Dengan demikian dapat disimpulkan bahwa senyawa 1 adalah asam 3,4-dihidroksi benzoat. Data NMR senyawa 1 dibandingkan dengan senyawa asam 3,4-dihidroksi benzoat. ${ }^{23}$ Hasil perbandingan menunjukkan bahwa kedua senyawa memiliki kesesuaian yang sangat tinggi, dengan demikian dapat disimpulkan bahwa senyawa 1 adalah asam 3,4-dihidroksi benzoat seperti yang ditunjukan pada gambar 1 dan tabel 2.

\section{Senyawa 2}

Senyawa 2 diperoleh berupa Padatan putih, t.l. $258-260^{\circ} \mathrm{C}$, UV (MeOH) $\lambda_{\text {maks }}$ nm 222 $(\log \varepsilon 3,7), 271(\log \varepsilon 3,0)$ dan $404(\log \varepsilon 1,6) ; I R$ (KBr) Umaks $\mathrm{Cm}^{-1}: 3422,1649,1408,1020 ; 1 \mathrm{H}-\mathrm{NMR}$ (aseton- $\left.d_{6}, 500 \mathrm{MHz}\right) \delta_{\mathrm{H}}(\mathrm{ppm}): 7,15(2 \mathrm{H}, \mathrm{s}, \mathrm{H}-2$, $\mathrm{H}-6) ;{ }^{13} \mathrm{C}-N M R$ (aseton- $\left.d_{6}, 125 \mathrm{MHz}\right) \delta_{c}(\mathrm{ppm})$ : 122,2 (C-1), 110,7 (C-2, C-6), 145,9 (C-3, C-5), 138,6 (C-4), dan 167,7 (C-7).

\section{Struktur Kimia Senyawa 2}

Senyawa 2 diperoleh berupa padatan putih dengan titik leleh $258-260^{\circ} \mathrm{C}$. Spektrum UV menunjukkan adanya dua pita serapan pada $\lambda_{\text {maks }} 271$ dan $222 \mathrm{~nm}$. Spektrum IR menunjukkan adanya gugus $-\mathrm{OH}$ yang teramati pada $v_{\text {maks }} 3422 \mathrm{~cm}^{-1}$ dan regang C$O$ pada $V_{\text {maks }} 1021 \mathrm{~cm}^{-1}$. Spektrum'H NMR senyawa 2 menunjukkan kehadiran satu sinyal proton singlet yang beresonansi pada $\delta_{H} 7,14$ ppm. Dua sinyal karbon masing-masing mewakili dua buah karbon, dengan demikian senyawa 2 ini memiliki struktur simetris. Spektrum ${ }^{13} \mathrm{C}$ NMR menunjukkan kehadiran tujuh sinyal karbon yang terdiri atas satu karbon karbonil yang beresonansi pada $\delta c 167,6 \mathrm{ppm}$ dan sinyal $\mathrm{CH} \mathrm{sp}^{2}$ yang beresonansi pada $\delta c 145,9-110,1$ ppm. Data
NMR senyawa 2 dibandingkan dengan senyawa asam galat. ${ }^{24}$ Hasil perbandingan menunjukan bahwa kedua senyawa memiliki kesesuaian yang sangat tinggi (Tabel 3), sehingga senyawa 2 diidentifikasi sebagai asam galat (Gambar 2).

\section{Senyawa 3}

Padatan putih, t.l. 298-301 ${ }^{\circ} \mathrm{C}$, UV $(\mathrm{MeOH}) \lambda_{\text {maks }} \mathrm{nm} 254(\log \varepsilon 3,2)$ dan 364 (log $\varepsilon$ 2,8); IR (KBr) Umaks $\mathrm{Cm}^{-1} 3429,1651,1437,1020$; 'H-NMR (aseton- $\left.d_{6}, 500 \mathrm{MHz}\right) 6,27(1 \mathrm{H}, d, J=2,0$ $\mathrm{Hz}, \mathrm{H}-6), 6,54(1 \mathrm{H}, \mathrm{d}, J=2,0 \mathrm{~Hz}, \mathrm{H}-8), 8,15(2 \mathrm{H}, d$, $\left.J=9,1 \mathrm{~Hz}, \mathrm{H}-2^{\prime} ; \mathrm{H}^{\prime} 6^{\prime}\right), 7,02(1 \mathrm{H}, d, J=9,1 \mathrm{~Hz}, \mathrm{H}-$ 3'; H-5'). ${ }^{13} \mathrm{C}-\mathrm{NMR}$ (aseton- $d_{6}, 125 \mathrm{MHz}$ ) $\delta c$ (ppm): 165,0 (C-2), 104,0 (C-3), 176,0 (C-4), 163,0 (C-5), 99,1 (C-6), 157,8 (C-7), 94,5 (C-8), $157,8(C-9), 108,0(C-10), 123,9(C-1 '), 130,5$ (C$\left.2^{\prime}, C^{\prime}-6^{\prime}\right), 116,3$ (C-3', C-5'), 163,0 (C-4').

\section{Struktur Kimia Senyawa 3}

Senyawa 3 diperoleh berupa padatan putih dengan titik leleh $298-301^{\circ} \mathrm{C}$. Spektrum UV senyawa 3 menunjukkan adanya dua pita serapan pada $\lambda_{\text {maks }} 254$ dan $364 \mathrm{~nm}$. Spektrum IR senyawa 3 menunjukkan adanya gugus $-\mathrm{OH}$ yang teramati pada $v_{\text {maks }} 3429 \mathrm{~cm}^{-1}$ dan regang C-O pada $V_{\text {maks }} 1020 \mathrm{~cm}^{-1}$. Adanya kerangka flavon ini didukung pula oleh spektrum 'H NMR yang menunjukkan adanya dua proton yang terjodoh secara meta pada $\delta_{H} 6,34(1 \mathrm{H}, d, 1,9)$ dan pada $\delta_{H}$ $6,11(1 \mathrm{H}, \mathrm{d}, 1,9)$ pada cincin B. Spektrum ${ }^{13} \mathrm{C}$ NMR menunjukkan adanya 15 sinyal karbon. Berdasarkan data DEPT 135, kelimabelas karbon tersebut terdiri atas tujuh metin sp2yang beresonansi pada daerah $\delta c 96,1$ 129,4 ppm, enam karbon kuartetner $s p^{2}$ teroksigenasi yang beresonansi pada medan lemah $\delta_{c} 159,8$ - 165,9 ppm, serta satu gugus karbonil yang beresonansi pada $\delta c$ 183,5 ppm. Data NMR senyawa 3 dibandingkan dengan senyawa apigenin dari tanaman desmotachia bipinnata (L). ${ }^{25}$ Hasil perbandingan menunjukkan bahwa kedua senyawa memiliki kesesuaian yang sangat tinggi (Tabel 4), sehingga senyawa 3 diidentifikasi sebagai apigenin (Gambar 3).

Setelah didapatkan 3 struktur kimia senyawa tersebut, kemudian lanjutkan dengan uji antiproliferasi ketiga senyawa tersebut, dan peroleh hasil I $c_{50}$ berturut turut 23,45 untuk senyawa 1, 17,92 untuk senyawa 2 dan 12,96 untuk senyawa 3 . Hasil lengkap Ic 50 tertera seperti pada tabel 5 .

Kesimpulan dari penelitian ini yaitu tiga senyawa telah disolasi dan merupakan senyawa yang baru ditemukan pada daun Rasamala yaitu asam-3,4 dihidroksi benzoat (1), asam galat (2), apigenin (3). Ketiga senyawa tersebut adalah metabolit sekunder dari daun Rasamala yang dapat menghambat prolierasi sel kanker lidah manusia in vitro. 


\section{UCAPAN TERIMAKASIH}

Terimakasih kepada direktur LPDP kementrian Keuangan Republik Indonesia yang telah mendanai penelitian ini.

\section{DAFTAR PUSTAKA}

1. Jemal A, Siegel R, Ward E, Hao Y, XU J, Thun MJ. Global Cancer statistics. CA Cancer J. Clin. 201 1; 59: 225-249.

2. Johnson NW, Warnakulasuriya S, Gupta PC, Dimba E, Chindia M, Otoh EC, Sankaranarayanan R, Califano J, Kowalski L. Global oral health inequalities in incidence and outcomes for oral cancer: Causes and solutions. Adv. Dent. Res. 201 1; 23: 237-246.

3. Bagan J, Sarrion G, Jimenez Y. Oral Cancer: Clinical Features. Oral Oncol. 2010; 46: 414-417.

4. Bello $I O$, Soini $Y$, Salo T. Prognostic Evaluation of Oral Tongue Cancer: Means, Markers and Perspectives (I). Oral Oncol. 2010; 46, 630-635.

5. Braakhuis BJ, Bloemena E, Leemans CR, Brakenhoff RH. Molecular Analysis of Surgical Margins in Head and Neck Cancer: More Than a Marginal Issue. Oral Oncol. 2010; 46, 485-491.

6. Shah JP, Gil Z. Current concepts in management of oral cancer- surgery. Oral Oncol. 2009; 45: 394-401.

7. Yen CY, Liang SS, Han LY, Chou HL, Chou CK, Lin SR, Chiu CC. Cardiotoxin III inhibits proliferation and migration of oral cancer cells through MAPK and MMP signaling. J scie world. 2013; 12: 324-340.

8. Manoharan S, Singh RB, Balakrishnan S. Chemopreventive Mechanisms of Natural Products in Oral, Mammary and Skin Carcinogenesis: An Overview. The Open nutraceutic. 2009; 2: 52-63.

9. Tan $W, L U$ J, Huang $M$, Li Y, Chen $M, W U$ G, Gong J, Zhong Z, XU Z, Dang Y, Guo J, Chen, X, Wang Y. Anti-cancer Natural Products Isolated from Chinese Medicinal Herbs. Chinese Med. 2011; 6: 27-37.

10. Bayala B, Bassole INH, Scifo R, Gnoula C, Morel L, Labaccaro JMA, Simpore J. Anticancer activity of essential oils and their chemical component. Am.J. cancer. Res. 2014; 4(6) 591-607.

11. Liu Z, Peiying Y, Newman RA. Sweet gum friut extract as a therapeutic agent. Pct int. Appl. 2010; 24 (5): 234-238.
12. Kuniyoshi S, Yuko F, Reiko T, Shunyo M, Takao Y. New cytotoxic oleanane- type triterpenoids from the cone of Liquidambar styraciflua. J Nat Prod. 2004; 67: 1088-1093

13. El-Readi MZ, Eid HH, Ashour ML, Eid SY, Labib RM, Sporer F, wink M. Variation of the Chemical Composition and Bioactivity of Essential Oils from Leaves and Stems of Liquidambar styraciflua (Altingiaceae). J. Pharm and Pharmacol. 2013; 65 (11): 1653-1663.

14. Zhang J, Chou G, Liu Z, Gar KH. In vitro Cytotoxicity and Antioxidation of a Whole Fruit Extract of Liquidambar formosana Exerted by Different Constituents. European Journal of Medicinal Plants 2015; 6(1): 34-44.

15. Shang HJ, Li DY, Wang, WJ, Li ZL, Hua HM. Three new diterpenoids from the resin of Liquidambar formosana. Nat Prod Res. 2013; 34(3): 127-13.

16. Kim HH, Yi HS, Hwan MO, Hyuk KH, Ra KS, Lee MW.. Anti oxidative and antiproliferative activity on Human Prostate Cancer Lines of the phenolic compounds from Corylopsis coreana Uyeki. 2013; 18: 4876-4888.

17. Jung US, Yoon JL, Park MH, Moon JB.. Anti-inflammatory compositions containing extracts of Corylopsis coreana and Erythronium japonicum. Molecules. 2014;

18. Pramono AA, Djam'an DF. Tumbuhan rasamala. Balai Penelitian dan Pengembangan Teknologi Perbenihan. Bogor. 2012.

19. Kanjilal PB, Kotoky R, Singh RS. Chemical composition of the leaf oil of Altingia excelsa Nornha. Flavour Fragr J. 2003; 18: 449-450.

20. Dewick PM. Medicinal Natural Product a Biosyntesis Approach. John Willey and Sons. London. 2009.

21. Supriatno. Cis- Platinum Meningkatkan Apoptosis dan Hambatan Invasi Sel Kanker Lidah Manusia in Vitro. MIKGI. 2008; 10: 73-78

22. Supratman U. Elusidasi Struktur Senyawa Organik. Edisi V. Jurusan Kimia FMIPA Unpad. Jatinangor. 2010.

23. Gurial M, Mitra P, Ghosh T, Gupta S, Basu B, Mitra PK. 3,4 diHidroxyBenzoic acid Isolated from the Leaves of Ageratum conyzoides L. EJBB. 2013; 1 (4): 25-28. 
24. Gangadhar $M$, Bhavana $P$, Sunil $Y$, Datta S. Isolation and Characterisation og Gallic Acid from Terminalia bellerica and its effect on Carbohydrate Regulatory Sistem In Vitro. IJRAP. 2011; 2(2): 559-562.
25. Awaad AS, Mohamed NH, Maitland DJ, Soliman GA. Anti-ulceragenic activity of extract and some isolated flavonoids from desmotachia bipinnata (L) stapf. Rec. Nat. Prod. 2008; 2(3):76-82. 